\title{
Estimation of Genetic Variability, Correlation and Path Analysis for Yield and Yield Contributing Traits in Chickpea (Cicer arietinum L.)
}

\author{
N.R. Thakur*, V.N. Toprope and Koppuravuri Sai Phanindra
}

Department of Genetics and Plant Breeding, College of Agriculture, Latur-413 512, India

*Corresponding author

\section{Keywords \\ Chickpea, Heritability, \\ Genetic advance, \\ Variability, \\ Correlation \\ Article Info \\ Accepted: \\ 20 January 2018 \\ Available Online: \\ 10 February 2018}

\section{A B S T R A C T}

Hundred germplasm lines of chickpea (Cicer arietinum L.) were grown in RBD with two replications under rain fed season at College of Agriculture, Latur. The maximum genotypic coefficient of variation was noticed for seed yield per plant (32.76\%), number of secondary branches $(32.6 \%)$, test weight $(31.28 \%)$, total number of seed per plant $(28.68 \%)$ and number of pods per plant $(25.7 \%)$. The high heritability in percent coupled with high genetic advance as percentage of mean was recorded by seed yield (75.13, $58.51)$, number of secondary branches $(80.63,60.31)$, number of pods per plant $(86.7$, $49.30)$, test weight $(90.16,61.18)$ and total number of seed per plant $(91.83,56.62)$ respectively, whereas, harvest index showing low heritability (38.27) with genetic advance as percentage of mean (8.82). Seed yield per plant showed high significant positive correlation with test weight (0.728), harvest index (0.439), total number of pods per plant (0.436), number of secondary branches (0.391) and total number of seeds per plant (0.366). Thus, the total pods per plant, total number of seeds per plant, 100 seed weight, secondary branches and seed yield per plant considered as selection criteria, while selecting superior genotypes under rain fed condition. High yielding advanced breeding lines viz. RVSGS 11, PG 12310, BDNG 807, PG 0749, ICC 107, ICC 111, ICC 15105 and G 94 were found suitable for crop improvement and breeding purpose.

\section{Introduction}

Chickpea (Cicer arietinum L.) is an important grain legume crop in India and plays a dominant role in the agriculture of Rabi rain fed areas of the country. It is the world's third most important food legume after soybean and pea. Out of total production and area of pulses, chickpea accounts for $37 \%$ and $28.28 \%$, respectively. India contributes the major share to the global chickpea area (65\%) and production $(68 \%)$ and produces around 8567.8 thousand tones of total pulse from an area of nearly 23 million hectares of land (Peerzada et al., 2014). Chickpea is the cheapest and most readily available source of protein $(19.5 \%)$, fat $(1.4 \%)$, carbohydrates (57-60\%), ash $(4.8 \%)$ and moisture (4.9-15.59\%) (Katiyar, 1982). It also helps to replenish soil fertility by fixing atmospheric $\mathrm{N}_{2}$ via symbiosis. It is rich and readily available source of protein both for human and animals. It makes up the deficiency of cereal diets. The average production of chickpea is low in the country which may be attributed to the lack of high 
yielding varieties, resistant to diseases and pests, high response to high inputs and other management practices.

The success of any crop improvement programs largely depends on the genetic variability present in the population. Heritability estimates are used to determine the amount of variation present in the population. Heritability combined with genetic advance will bring out the genetic gain expected from selection (Kumar et al., 2013). The knowledge of inter-relationships between different characters is important in breeding direct and indirect selection of characters that are not easily measured and those with low heritability. However, it is self pollinating and possesses limited variability. The knowledge of genetic variability and relationships among characters in germplasm will help in the selection and breeding of high yielding, good quality cultivars that will increase production. Keeping the above points in view, this study was carried out in 100 chickpea germplasm lines to assess the variability, heritability, genetic advance and interrelationships between yield and its components and the direct and indirect effects of some quantitative characters.

\section{Materials and Methods}

In the present study hundred genotypes were sown in randomized complete block design (RBD) with two replications at Experimental Farm, College of Agricultural, Latur (M.S.) during Rabi 2016-17. Each genotype was raised in $5 \mathrm{~m}$ length with spacing of $30 \times 10$ $\mathrm{cm}$. Recommended agronomic practices were followed to raise a good crop. Observations were recorded on days to $50 \%$ flowering, days to maturity, plant height $(\mathrm{cm})$, number of primary branches plant ${ }^{-1}$, number of secondary branches $^{-1}$, total pods plant ${ }^{-1}$, total number of seeds plant ${ }^{-1}, 100$ seed weight $(\mathrm{g})$, seed yield plant $^{-1}(\mathrm{~g})$, and harvest index $(\%)$. The data were recorded on five randomly selected plants in each entry in each replication. The mean values were used for analysis of variance by following Panse and Sukhatme (1967). The coefficient of variation was calculated as per Burton (1954). Heritability in broad sense and genetic advance were calculated as per Johnson et al., (1955). Correlation coefficients at phenotypic and genotypic level were computed as per the methods suggested by Al-Jibouri et al., (1958). Path coefficients were estimated according to Dewey and Lu. (1959).

\section{Results and Discussion}

In the present study the analysis of variation shown highly significant differences among the genotypes for all the characters studied viz., days to $50 \%$ flowering, days to maturity, plant height $(\mathrm{cm})$, number of primary branches plant $^{-1}$, number of secondary branches ${ }^{-1}$, total pods plant ${ }^{-1}$, total number of seeds plant ${ }^{-1}, 100$ seed weight $(\mathrm{g})$, seed yield plant $^{-1}(\mathrm{~g})$, and harvest index (\%) indicating thereby the wide range of genetic variability and scope of selection for these traits. Similar result has been reported by Dehal et al., (2016) and Kumar et al., (2014). The variation of different traits under this study revealed that the Phenotypic coefficient of variation (PCV) were invariably slightly higher than Genotypic coefficient of variation (GCV) for all the characters studied except harvest index indicating the role of environmental variance in the total variance (Table 1). The high PCV and GCV were observed for seed yield per plant (37.8 and $32.76 \%$ ) followed by number of secondary branches per plant (36.32 and $32.6 \%$ ), 100 seeds weight (32.94 and 31.28\%) total number of seeds per plant (29.93 and $28.68 \%$ ), number of pods per plant (27.61 and $25.75 \%$ ) and number of primary branches per plant (23.59 and 19.75\%), respectively indicating that these traits were main yield contributing characters. High value of PCV 
and GCV for these traits have also been reported by Vaghela et al., (2009), Qurban et al., (2011), Ali et al., (2011), Gaikwad et al., (2011), Shweta et al., (2013) and Peerzada et al., (2014). Moderate PCV and GCV were recorded for plant height (14.22 and 13.1\%) and days to $50 \%$ flowering (12.86 and $12.3 \%$ ), where as lowest PCV and GCV were recorded by harvest index (11.19 and 6.93\%) and days to maturity (3.81 and 3.33\%). The presence of high amount of genetic variability in the evaluated germplasm for the major yield contributing characters along with seed yield indicating that further improvement of these traits is possible. These findings suggest that selection can be effective based on phenotypic along with equal probability of genotypic values.

With the help of GCV alone, it is not possible to determine the extent of variation that is heritable. Hence, the knowledge of heritability helps the plant breeders in prediction. The genetic advance for quantitative characters aids in exercising necessary selection procedure. An estimate of heritable fraction of variability is of paramount importance in any crop improvement programme.

The present study revealed that estimates of broad sense heritability (Table 1) were high (>70\%) for number of seed per plant $(91.83 \%)$ followed by days to $50 \%$ flowering $(91.5 \%)$, test weight $(90.16 \%)$, number of pods per plant (86.37\%), plant height (84.81\%), Number of secondary branches per plant (86.63) and seed yield per plant (75.13\%). Remaining trait like harvest index showed low estimates of heritability $(38.30 \%)$. High heritability for these traits have earlier been reported by Ali et al., (2011), Kumar et al., (2014), Waseem et al., (2014), Sachin et al., (2014) and Mohamed et al., (2015). The genetic advance as per cent of mean was higher for 100 seeds weight (61.18), secondary branches (60.31) followed by seed yield per plant (58.71), number of seeds per pod (56.62) and number of pods per plant (49.30) indicating that direct selection for these traits would be effective for the improvement. Similar findings related to high genetic advance as per cent of mean for various traits have also been reported by Vaghela et al., (2009), Tomar et al., (2009) and Kumar et al., (2014). High heritability and low level of differences among PCV and GCV for studied traits indicated that cultivar influence more in expression of these traits. The character having high heritability coupled with high genetic advance generally indicates that heritability is more due to the additive gene effect and advocated the use of high estimates of heritability along with high magnitude of genetic advance for genetic improvement in any trait through selection. High heritability coupled with high genetic advance as per cent of mean was observed for 100 seeds weight, number of pods per plant, seed yield per plant and number of seeds per pod.

High heritability coupled with high genetic advance as per cent of mean for seed yield per plant and number of pods per plant has also been reported by Shweta et al., (2013), Vaghela et al., (2009), Waseem et al., (2014) and Kumar et al., (2014).

Yield is a complex quantitative character governed by large number of genes and is greatly affected by environment. Hence, the selection of superior genotypes based on yield will not give a fruitful result. Association of yield components and yield thus, assumed special importance as the basis for selecting desired strains. Genetic correlation between different characters often arises due to its tight linkage or pleiotropy. The results on phenotypic and genotypic correlation between yield and its components in the present investigation are presented in Table 2 . 
Table.1 Estimates of range, Mean, genotypic and phenotypic coefficient of variation (GCV and PCV), heritability and genetic advance as per cent of mean for 10 quantitative characters in chickpea

\begin{tabular}{|c|c|c|c|c|c|c|}
\hline Characters & Range & Mean & GCV $(\%)$ & $\operatorname{PCV}(\%)$ & Heritability (B.S.) & GA as \% Mean \\
\hline Days to $50 \%$ Flowering & $33.00-65.50$ & 47.14 & 12.3 & 12.86 & 91.5 & 24.24 \\
\hline Days to maturity & $98.00-120.50$ & 106.94 & 3.33 & 3.81 & 76.11 & 6.0 \\
\hline Plant Height (cm) & $26.40-57.99$ & 45.64 & 13.1 & 14.22 & 84.81 & 24.85 \\
\hline Number of Primary branches & $1.9-4.5$ & 3.19 & 19.7 & 23.59 & 67.76 & 33.9 \\
\hline Number of Secondary branches & $0.0-12.04$ & 5.99 & 32.6 & 36.32 & 80.63 & 60.31 \\
\hline Number of pods per plant & $12.73-60.24$ & 30.29 & 25.7 & 27.61 & 86.7 & 49.30 \\
\hline Total number of seed per plant & $17.31-62.37$ & 31.21 & 28.68 & 29.93 & 91.83 & 56.62 \\
\hline Test weight (g.) & $8.5-56$ & 25.78 & 31.28 & 32.94 & 90.16 & 61.18 \\
\hline Harvest index (\%) & $38.43-63.57$ & 49.7 & 6.93 & 11.19 & 38.3 & 8.82 \\
\hline Seed yield/plant (g.) & $3.4-14.3$ & 7.7 & 32.76 & 37.8 & 75.13 & 58.51 \\
\hline
\end{tabular}

Table.2 Genotype (above diagonal) and phenotypic (Lower diagonal) correlation of different characters in chickpea

\begin{tabular}{|c|c|c|c|c|c|c|c|c|c|c|}
\hline Characters & DF & DM & $\mathbf{P H}$ & NPB & NSB & NPP & TNSP & TW & HI & SYP \\
\hline DF & 1.000 & $0.5537 * *$ & $0.2245 * *$ & $0.1522 *$ & $0.2107 * *$ & $0.1629 *$ & 0.1153 & -0.0391 & -0.0079 & 0.0243 \\
\hline DM & $0.4880 * *$ & 1.000 & -0.0608 & $0.2212 * *$ & $0.2084 * *$ & 0.0939 & 0.0283 & 0.1268 & $0.1767 *$ & $0.1865 * *$ \\
\hline $\mathbf{P H}$ & $0.1742 *$ & -0.0554 & 1.000 & 0.0226 & -0.1435 & $0.1537 *$ & $0.1703^{*}$ & -0.0121 & $-0.3007 * *$ & 0.065 \\
\hline NPB & 0.1295 & $0.1726^{*}$ & -0.0096 & 1.000 & $0.4354 * *$ & $0.206^{* *}$ & $0.2962 * *$ & 0.0041 & $0.187 * *$ & $0.2665 * *$ \\
\hline NSB & $0.1594 *$ & $0.1660^{*}$ & -0.094 & $0.2956 * *$ & 1.000 & $0.3611 * *$ & $0.4297 * *$ & 0.056 & $0.1831 * *$ & $0.3915 * *$ \\
\hline NPP & $0.1491 *$ & 0.076 & 0.1293 & $0.1552 *$ & $0.3256 * *$ & 1.000 & $0.8892 * *$ & $-0.2082 * *$ & 0.0088 & $0.4364 * *$ \\
\hline TNSP & 0.110 & 0.0212 & $0.1442 *$ & $0.2186 * *$ & $0.3829 * *$ & $0.8613 * *$ & 1.000 & $-0.3244 * *$ & -0.0541 & $0.3667 * *$ \\
\hline TW & -0.0428 & 0.0956 & -0.0121 & 0.0008 & 0.033 & $-0.1827 * *$ & -0.291 & 1.000 & $0.4442 * *$ & $0.73 * *$ \\
\hline $\mathrm{HI}$ & -0.0303 & 0.092 & $-0.1658 *$ & 0.1117 & 0.1055 & -0.0168 & -0.0587 & $0.2490 * *$ & 1.000 & $0.4396 * *$ \\
\hline SYP & 0.0279 & 0.0955 & 0.0764 & $0.1579 *$ & $0.3514 * *$ & $0.4203 * *$ & $0.3496 * *$ & $0.6436^{* *}$ & $0.3395 * *$ & 1.000 \\
\hline
\end{tabular}

$*=0.05$ level of significance $* *=0.01$ level of significance.

$\mathrm{DF}=$ Days to $50 \%$ flowering, $\mathrm{DM}=$ Days to maturity, $\mathrm{PH}=$ Plant height $(\mathrm{cm}), \mathrm{NPB}=$ Number of primary branches, NSB $=$ Number of secondary branches, $\mathrm{NPP}=$ Number of pods per plant, TNSP $=$ Total number of seeds per plant, $\mathrm{TW}=$ Test weight $(\mathrm{gm}), \mathrm{HI}=$ Harvest index $(\%), \mathrm{SYP}=\mathrm{Seed}$ yield per plant. 
Table.3 Direct (diagonal) and indirect (off diagonal) effects of contributing characters on seed yield in chickpea

\begin{tabular}{|c|c|c|c|c|c|c|c|c|c|c|}
\hline Characters & DF & DM & PH & NPB & NSB & NPP & TNSP & TW & HI & SYP \\
\hline DF & -0.079 & -0.0437 & -0.0177 & -0.012 & -0.0166 & -0.0129 & -0.0091 & 0.0031 & 0.0006 & 0.0243 \\
\hline DM & 0.031 & 0.056 & -0.0034 & 0.0124 & 0.0117 & 0.0053 & 0.0016 & 0.0071 & 0.0099 & 0.1865 \\
\hline PH & 0.003 & -0.0008 & 0.0133 & 0.0003 & -0.0019 & 0.002 & 0.0023 & -0.0002 & -0.004 & 0.0680 \\
\hline NPB & 0.009 & 0.013 & 0.0013 & 0.059 & 0.0257 & 0.0121 & 0.0175 & 0.0002 & 0.011 & 0.2665 \\
\hline NSB & 0.0113 & 0.0112 & -0.0077 & 0.0234 & 0.0538 & 0.0194 & 0.0231 & 0.003 & 0.0099 & 0.3915 \\
\hline NPP & 0.0332 & 0.0191 & 0.0313 & 0.042 & 0.0736 & 0.2039 & 0.1813 & -0.0425 & 0.0018 & 0.4364 \\
\hline TNSP & 0.0505 & 0.0124 & 0.0746 & 0.1297 & 0.1882 & 0.3894 & 0.4379 & -0.142 & -0.0237 & 0.3667 \\
\hline TW & -0.0344 & 0.1116 & -0.0107 & 0.0036 & 0.0493 & -0.1833 & -0.2855 & 0.8802 & 0.391 & 0.7282 \\
\hline HI & -0.0003 & 0.0076 & -0.013 & 0.0081 & 0.0079 & 0.0004 & -0.0023 & 0.0192 & 0.0431 & 0.4396 \\
\hline
\end{tabular}

$\mathrm{R}^{2}=0.9557$ Residual effects $=0.2106$

$\mathrm{DF}=$ Days to $50 \%$ flowering, $\mathrm{DM}=$ Days to maturity, $\mathrm{PH}=$ Plant height $(\mathrm{cm}), \mathrm{NPB}=$ Number of primary branches, $\mathrm{NSB}=$ Number of secondary branches, $\mathrm{NPP}=$ Number of pods per plant, TNSP $=$ Total number of seeds per plant, TW $=$ Test weight $(\mathrm{gm}), \mathrm{HI}=$ Harvest index $(\%), \mathrm{SYP}=\mathrm{Seed}$ yield per plant. 
The correlation analysis revealed that the genotypic correlation coefficient were higher than phenotypic values indicating that strong intrinsic association are reduced at phenotypic level due to environmental effects.

Seed yield was positively and significantly associated with test weight (0.73), harvest index (0.439), number of pods per plant (0.436), secondary branches per plant $(0.391)$ and total seeds per plant (0.366) (Table 2). The results corroborate the finding of Jeena et al., (2005) and Dehal et al., (2016).

Total number of seed per plant showed significant positive correlation with number of pods per plant 0.8892), Number of secondary branches (0.4297), number of primary branches (0.2962) and plant height (0.1703). These results clearly indicate that indirect selection for seed yield in chickpea can be based on these traits. Similar finding are reported by Babbar et al., (2012).

Significant negative correlation was noticed for 100 seed weight with total number of seeds per plant $(-0.324)$ and number of pods per plant $(-0.208)$ and harvest index with plant height (-0.3007). Babber et al., (2012) also reported negative correlation for 100 seed weight with total number of seeds per plant and number of pods per plant.

Path coefficient analysis was carried out by taking seed yield per plant as dependent variables and rest of the quantitative traits as independent variables (Table 3). Path coefficients for seed yield per plant recorded the highest positive direct effect contributing to seed yield plant ${ }^{-1}$ is, harvest index followed by biological yield, pods plant-1, primary branches plant-1 plant height, days to $50 \%$ flowering. Whereas, negative direct effects on seed yield per plant were observed due to days to maturity and 100 seed weight. Similar results were reported by Farshadfar and
Farshadfar (2008), Vaghela et al., (2009), Borate et al., (2010) and Pandey et al., (2013).

Test weight (0.8802), total number of seed per plant (0.4379) and number of pods per plant 90.2039) had positive direct effects on seed yield per plant. Highest indirect effects were noticed for number of pods per plant via total number of seeds per plant (0.3894) and number of secondary branches via total number of seeds per plant $(0.1882)$.

Thus, the present study suggests that selection for high seed yield should be based on total number of seeds per plant, number of pods per plant, number of secondary branches and test weight in chickpea. Therefore, due emphasis may be given on these characters for selecting high yielding genotypes in chickpea.

\section{References}

Al Jibouri, H.A., Millar, P. A. and Robinson, H.F. 1958. Genotypic and environmental variances and covariances in an upland cotton cross of inter-specific origin. Agronomy Journal 50: 633-636.

Ali, Q., Tahir, M. H. N., Sadaqat, H. A., Arshad, S., Farooq, J., Ahsan, M., Waseem, M. and Iqbal, A. 2011. Genetic variability and correlation analysis for quantitative traits in chickpea genotypes (Cicer arietinum L.). Journal of Bacteriological Research 3: 6-9

Babbar, A. Prakash, V. Tiwari, P. and Iquebal, M.A.2012. Genetic variability for chickpea under late sown condition. Legume Res. 35(1):1-7.

Borate, V.V., Dalvi, V.V. and Jadhav, B.B. 2010. Estimates of genetic variability and heritability in chickpea. J. Maharashtra Agric. Univ., 35(1): 47-49.

Burton, G.W.1954. Quantitative inheritance in grasses. Proceedings of $6^{\text {th }}$ International Grassland Congress, 1: 277-283.

Dehal, I.N., Rama Kalia and Bhupendar Kumar. 2016. Genetic estimates and path coefficient analysis in chickpea (Cicer arietinum L.) 
under normal and late sown environments. Legume Research, 39 (4): 510-516.

Dewey, D.R. and Lu, K.H. 1959. A correlation and path coefficient analysis of components of crested wheat grass seed production. Agronomy Jounral 51: 515-518.

Farshadfar, M. and Farshadfar, E. 2008. Genetic variability and path analysis of Chickpea (Cicer arietinum L.) land races and lines. $J$. Applied Sci. 8: 3951-3956.

Gaikwad, A.R., Desai, N.C., Langhi, A.M. and Jadhav, S.D.2011. Studies on genetic variability in chickpea (Cicer arietinum L.). Eco., Envnt. Conservation, 17: 585-588.

Jeena, A.S., Arora, P.P. and O.P. Ojha. 2005. Variability and Correlation studies yield and its components in chickpea (Cicer arietinum L.). Legume Res., 28(2): 146-148.

Johnson, R.E., Robinson, H.W., Comstock, H.F. 1955.Estimates of genetic and environmental variability in soybean. Agronomy Journal.; 47:314-318.

Katiyar, R.P.1982. Accelerating pulse production in Himachal hills. Seeds and Farms, 8:38-42

Kumar, R., Kuldeep, Pandey, S., Babbar, A. and Mishra, D.K.2014. Genetic variability, character association and path coefficient analysis in chickpea grown under heat stress conditions. Electronic J. Pl.Breed., 5: 812819.

Kumar, S. R., Arumugam, T., Anandakumar, C. R. and Premalakshmi, V. 201). Genetic variability for quantitative and qualitative characters in Brinjal (Solanum melongena L.). African Journal of Agricultural Research 8: 4956-4959.

Mohamed, A.A., Tahir, I.S.A. and Elhashimi, A.M.A.2015. Assessment of genetic variability and yield stability in chickpea (Cicer arietinum L.) cultivars in River Nile State, Sudan. J. Plant Breed. Crop Sci., 7: 219-224.
Pandey, A., Gupta, S., Kumar, A., Thongbam, P. D. and Pattanayak, A. 2013. Genetic divergence, path coefficient and cluster analysis of chickpea (Cicer arietinum L.) cultivars, in the mid-altitudes of Meghalaya. Indian J. Agril. Sci. 83(12): 1300-1304.

Panse, V.G. and Sukhatme, P.G. 1967. Statistical Methods for Agricultural Workers. 2nd Edn. ICAR, New Delhi. pp. 381

Peerzada, O.H., Chaurasia, A.K. and Ahmad, Q.I.2014. Evaluation of chickpea germplasm (desi) (Cicer arietinum L.) for yield and yield contributing traits. The bioscan, 9: 1805-1809.

Qurban, A., Mohammod, A.J. and Farooq, M.S.2011. Genetic variability and traits association in chickpea. Electronic J. Pl. Breed., 1: 328-333.

Sachin, D.P., Harer, P.N. and Nagawade, D.R.2014. Investigation of genetic divergence in chickpea (Cicer arietinum L.) genotypes. The Bioscan, 9: 879-882.

Shweta, Yadav, A.K. and Yadav, R.K.2013. Studies on genetic variability, heritability and genetic advance in chickpea (Cicer arietinum L.). J. Food Leg., 26: 139-140.

Tomar, O.K., Dhirendra Singh and Singh, D.2009. Assessment of genetic diversity of cultivated chickpea. Asian J. Agri. Sci., 1: 7-8.

Vaghela, M.D., Poshiya, V.K., Savaliya, J.J., Kavani, R.H. and Davada, B.K. 2009. Genetic variability studies in Kabuli chickpea (Cicer arietinum L. Legume Res., 32(3): 191-194.

Waseem, M., Ali, Q., Ali, A., Samiullah, T.R., Baloch, D.M., Ahmad, S., Khan, M.A., Ali, S., Muzaffar, A., Abbas, M.A., Nasir, I.A. and Husnain, T. 2014. Genetic analysis for various traits of Cicer arietinum under different spacing. Life Sci. J., 1: 14-21

\section{How to cite this article:}

Thakur, N.R., V.N. Toprope and Koppuravuri Sai Phanindra. 2018. Estimation of Genetic Variability, Correlation and Path Analysis for Yield and Yield Contributing Traits in Chickpea (Cicer arietinum L.). Int.J.Curr.Microbiol.App.Sci. 7(02): 2298-2304.

doi: https://doi.org/10.20546/ijcmas.2018.702.278 